\title{
A Critical Analysis of North-South Continuity of Landmasses across Indus-Yarlu-Tsangpo Suture Zone: Its Bearing on the Himalayan Evolution
}

\author{
Zahid A. Khan ${ }^{1}$ and Ram Chandra Tewari $^{2}$ \\ ${ }^{1}$ 504, W.R.Apartments, Lalbagh, Lucknow-226001, India. \\ ${ }^{2}$ Department of Geology, Sri J.N.P.G.College, Lucknow-226001, India. \\ Email: ram.tewari9@gmail.com
}

\begin{abstract}
Gondwana glaciations are well known from the India, and therefore the Pole must have lingered long enough in the subcontinent to deposit some $1600 \mathrm{~m}$ thick glacio-marine sediments in northern Tibet. Similarities of these deposits with those of basal Gondwana Talchir rocks indicate that India and Tibet (and hence the rest of Asia) were united in the Upper Carboniferous and Lower Permian. Further, paleo-biogeography of the region suggests their continuity through Permian, Triassic and Jurassic, and up to Cretaceous. The collision is supposed to have taken place in the Eocene-Miocene, and there should at least have been a very short time of compression at this stage. Instead, the immense batholiths intrusion in the area strongly suggests tension. Moreover, the ophiolites along the suture have yielded two different ages of emplacement, Jurassic-Lowest Cretaceous, and then a little later in Lower Cretaceous, i.e. the emplacement took place $100 \mathrm{Ma}$ before the supposed collision in the Eocene. It is believed that the Indian Plate is progressively underthrusting the Tibetan Plate, though a large part of central and southern Tibet is traversed by active normal and transform faults and rift valleys, cutting across the Bongong-Nujiang and the Indus-Tsangpo suture zone and entering the Himalayan region imply tension all over the area, and not compression, that is expected from subduction/collision zone. Thus, the modern global plate tectonic concept and subduction/collision mechanism are thus, untenable for Himalaya evolution. Alternatively the Himalayas are formed under tensional regime by vertical uplift, intrusive magmas, boudins, sills sand dykes. Gravity gliding played an important role.

The various geological arguments such as structure, paleo-biogeography, paleoclimate and volcanic history, including the presence of Tibetan glacial deposits therefore, do not convincingly support the concept of collision of two landmasses, as popularly believed today or by the plate convergence and the hypothetical subduction in this part of world. Even the Paleomagnetic data is replete with contradictory evidence. The collisional along the Indus-Tsangpo suture is, therefore, doubtful in as much as India has all along been adjacent to Tibet, certainly at least since the Ordovician, and hence a part of the great Pangaea landmass. The modern global plate tectonic concept and subduction mechanism are, thus, untenable for Himalayan evolution. The Himalaya is formed under tensional regime by vertical uplift and gravity sliding.
\end{abstract}

Keywords: Plate tectonics, Himalaya, tibetan glacial deposit, continental collision.

\section{Introduction}

Indus-Yarlu-Tsangpo Suture (IYTS) belt of Indo-Tibetan region is the type suture, and, indeed has provided evidences for the collision of tectonic plates under widely recognized plate tectonic concept in the last about five decades or so. The Greater India therefore broke away from Pangaea in the late Paleozoic and moved to about $35^{\circ} \mathrm{S}$ latitude, near Madagascar, and then, returned to join the Pangaea landmass in the Eocene-Oligocene, exactly in its original place. Some $3500 \mathrm{~km}$ of oceanic crust is, thus, believed to have been subducted along this suture during collision and underthrusting of Indian plate. However, the suture ends abruptly against Jurassic phyllites intruded by $40 \mathrm{Ma}$ old granites at Rinbun (Figure 1) southwest of Lhasa (north of Myanmar). Also, there is no trace suture further east and hence it is identified as different features from Thailand to the western part of Myanmar, almost arbitrary. 
This raises a very important question. If, as envisaged by modern global tectonics, there was an ocean between the Indian and the Tibetan plates, and the Indus-Yarlu-Tsangpo feature marks the zone of subduction, collision and obduction, in front of the north ward moving Indian plate, where is the subduction zone in front of the Assam area? It, too, must have moved northward almost as much as the rest of India. It therefore requires suitable explanation regarding the nature of suture in front of Assam that falls east of Rinbun, and also the part of the subducted ocean.

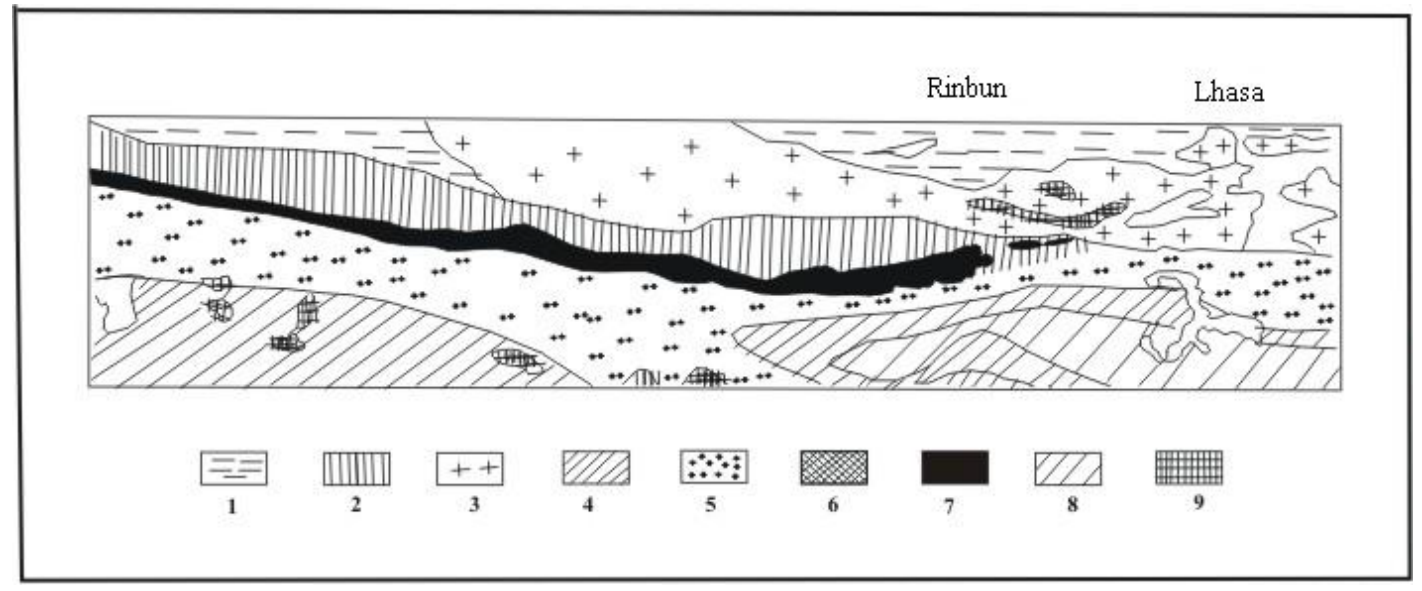

Figure 1. The Indus-Yarlu-Tsangpo Suture ends abruptly at Rinbun, southwest of Lhasa, against Jurassic slate. Farther east there is no trace of any suture. 1-Lingzizong Formation; 2-Xigaze Group; 3-Triassic Flysch; 4-Jurassic Sediments; 5-Gangdise Belt; 6-Himalyan Granites; 7-Ophiolite; 8-Cretaceous Sediment; 9-Lhasa Granite.

Modern global tectonics has introduced a syndrome of mobility in micro-,mini-, and mega-continents that repeatedly broke away and then returned to rejoin, to suture, with the mother landmass, almost invariably in their original locations, till Pangaea finally broke up, beginning around the Triassic. The motive force for the breaking away, the mid-ocean ridges, are recognized only since Mesozoic or Late Paleozoic, but what mechanism was responsible for the earlier break-ups is not specified, for no remnant of an earlier ocean, leave aside a mid-oceanic ridge, seems to exist. Thus, whereas the oldest age recorded from the continental areas is of $3.8 \mathrm{Ga}$, nowhere the oceans are older than $2.25 \mathrm{Ga}$, which corresponds to the final break-up of Pangaea. It may be explained by the subduction of the oceanic areas, however, it is amazing that nowhere has an older oceanic crust survived, or at least none has been discovered to date.

An outstanding geological feature is the presence of the glacial deposits of about $1600 \mathrm{~m}$ thick extending over thousands square kilometers in the northern and southern Tibet. The occurrence of these deposits has been considered as a "serious constraint to plate tectonic speculation" (Sino-French team, 1981), though subsequently in 1984, the same team interpreted these deposits as "rift in-fills". The Gondwana affinity fauna and flora described from these deposits (Wang Naiwen, 1984; Xu Baowen et al., 1984) does not justify rift-in-fill deposition and support the continuity of landmass to the north and south of the Indus-Yarlu-Tsangpo suture.

The paper analyzes the north-south continuity of the landmass across IYTS in light of various geological and tectonic evidences including the presence of Tibetan glacial deposits and the similarity of fauna and flora does not convincingly support the concept of collision of two landmasses, as popularly believed today or by the plate convergence and the hypothetical subduction in this part of world. Such geological factors should have important bearing on the widely accepted collision, suturing and underthrusting of Indian Plate. The modern global plate tectonic concept and subduction/collision mechanism are, thus, untenable for Himalayan evolution. Alternatively, the Himalaya is formed under tensional regime by vertical uplift and gravity sliding. 


\section{Tibetan Glacial Deposits}

The unexpected discovery of the Gondwana glacial deposits from Xainxa northern Tibet as well as from Zadre Formation in southern Xizang is rather interesting. The similar sequences are also known from western Afghanistan, and were soon reported from three different localities in southern Saudi Arabia. There was, thus, no place for an independent super-continent in the southern hemisphere. Noteworthy also is the fact that with Europe and North America over the equator, and Antarctica, as parts of a Pangaea, over the South Pole, the Earth has got to have been of a much smaller diameter.

The $1600 \mathrm{~m}$ thick Tibetan glacial deposits, with erratic exceeding 5-7 $\mathrm{m}$ in diameter underlying Permo-Carboniferous discovered by Norin (1946), and later confirmed by Bally, et al., (1980) cover thousands of sq. $\mathrm{km}$ in and across the Himalaya up to the northern Tibet and in Tenesserim-Malaysian block (Han Tongling and Wang Naiwen, 1983; Acharyya, 1992; Sinha, 2002). Tibet, then, must have been in the temperate latitudes of the southern hemisphere. These rocks contain fauna of Gondwana affinities, including Stepanoviella and Eurydesma, and, locally, the Glossopteris flora (Wang Naiwen, 1984). Xu Baowen et al., (1984) have recorded Late Paleozoic diamictite containing warm-cold water fauna in the upper part of the Pangduo Group at Lhasa-Liuzhou, with Stepanoviella fossils of cold water. The diamictite occurs north of Bongong, Lake Dongqiao and elsewhere further north and is covered by warm water fauna. Metcalfe (2001, p. 335) concluded that glacial diamictite associated cold water fauna and floras of early Permian are also found distributed along the entire length of East and Southeast Asia continental fragments and indicate attachment the margin of Great Gondwanaland. All the facts have obviously proven that prior to the early Permian, Xizang was an integral and unified continental structural region. And early Permian (280-270Ma) basal diamictite and associated sediments containing Noeggerathiopsis, Gangamopteris and Equisatalian flora, and palynomorphs in Tibetan glacial deposits have also been correlated with the Lower Gondwana Talchir Formation and the Blaini Boulder Bed of Indian subcontinent (Upadhyay et al., 1999).

Lin Baoyu (1980) points out that "In early Permian both flanks of Yarlu-Zhangbo River belonged to the same biographical realm" with common brachiopod and other cold water fauna, whereas Tibetan bryozoans were closely related with those of Pamir, Afghanistan, Thailand, Timor, Malaysia and Australia (Metcalfe, 1996) and those from the north and south of Yarlu-Tsangpo are identical (Liu Xiaoliang, 1981, p. 40). Similarly, Qui Hongrong (1980) from his studies concluded notes that Paleozoic and Triassic conodonts from the two sides of the Yarlu-Tsangpo are identical. Also, these glacial deposits not only carry Eurydesma, Stepanoviella, Marginifera, Neospirifer etc. as also elements of Glossopteris flora (Fan Yingnian, 1984) but also suggest that the ice moved from south to north. Other Gondwana floral elements include Noeggerathiopsis hislopi, Schizoneura, Phylotheca and others from the Lhasa Block. Han Tongling and Wang Naiwen (1983), concluded that the glacial deposits suggest that "Qinghai-Xizang, as well as the Indian Shield was (were) united as a paleo-continent and is (were) indivisible elements of the Great Gondwanaland".

Lower Paleozoic sequences and faunas of the Qaidam, Kunlun, and Ala Shan Blocks are similar to those of the Tarim Block and also to South and North China (Chen and Rong, 1992), and these blocks are perhaps disrupted fragments of a large Tarim terrane. This biogeographic data suggests that North China, South China, Indochina and Lhasa and Qiangtang Blocks formed the northern Gondwana in the early Paleozoic. And the close faunal affinities suggest continental contiguity of these blocks with each other and had originally been part of Great Gondwana at this time (see: Metcalfe, 2001).

Tapponnier et al., (1981), emphasized that "somewhat surprisingly there seems to be no unambiguous paleontological evidence of the Gondwana origin of the Lhasa Block, as doubts can be raised on the origin and significance of the Damsung-Lhinzu tillite". Chang Chengfa et al., 1986: Metcalfe, 2001), suggested that the glacial deposits had Gondwana affinities, and admitted that the "Lhasa Terrane was derived from Gondwanaland", also that the "Terrane was still a part of Gondwanaland in the early Permian". Tapponnier et al., (1981, p. 22) conclude that "Lhasa Terrane is a Cathaysian block and not necessarily of Gondwana origin". They thus denied the very existence of the Gondwana flora and fauna, just because Tibet as a part of Gondwanian block did not fit in with their plate tectonic concept. But what have they say about "the Carboniferous and Early Permian tillite, concurrent cold water fauna and Glossopteris flora found over a large expanse on the Qinghai Tibet plateau' (Wang Naiwen, 1984; Metcalfe, 2001) or that "Dicynodontdae, the terrestrial animal of Permian to Triassic, long 
supposed to be a representative of southern continent biota is now discovered in Tulufang, Tianshang in China. Allegre et al., (1984) interpreted the same deposits as "rift in-fills", instead of glacial origin. However, apart from their inherent characters, how could rift in-fills be spread all over northern Tibet, without there being thousands of rift valleys in the plateau?

The continental fragments on which these glacial-marine deposits occur (Boashan, Qiangtang) and Lhasa Block also have typical late Paleozoic Gondwana and cold climate indicative including oxygen isotope signatures (Metcalfe, 1998) consequently ruled out that the Indus- Yarlu-Tsangpo was the suture between Indian and Tibet.

\section{$3 \quad$ Paleontological Evidences}

Significantly the Kashmir Permian vertebrate fauna comprising Archaegosaurus, Actinodont, and Lysiptergium is identical with Permian vertebrates of Europe, China and Africa (Sun Ai Lin, 1972; Ahmad, 1978; Romer, 1973). Also, the Mesozoic sediments in the Lhasa Block overlying Permian glacigene are of shallow marine origin (Chang Chengfa et al., 1986), and farther north, beds of fresh water origin carry typical Triassic vertebrates of Gondwanaland affinities. These include Lystrosaurus, Preteresuchus, Tritilodon, Metaposaurus, Platosaurus and a number of other forms from Sinkiang, Shansi and Korea; Lystrosaurus, having been present in Europe, South and East Africa and Antarctica as well provide evidence for a single landmass over the Earth. The presence of these similar vertebrates in India and China simultaneously can be explained with a vast land-bridge connecting the two areas, and rules out the envisaged oceanic Tethys in the form of a triangle reaching up to Black sea or farther west. Ahmad (1978) has discussed the occurrence of a number of common forms between the northern and southern continents, including ammonites, fresh water fauna, and even insects, all of which could not even cross the narrowest oceanic area intervening between India and China. Further, Qui Hongrong (1980) has described conodonts common to the two flanks of the Indus-Tsangpo suture in the Paleozoic and the Triassic. Detailed field study in the Karakoram and Tibet suggests that the given sediments of the southern and northern sides of the Indus-Yarlu-Tsangpo suture are genetically identical. The faunal analysis, using Q- mode cluster analysis, suggested that these are similar to each other on both sides of the Indus suture, and could not have been separated during Permian by an ocean (Waterhouse and Bonham-Carter, 1975; Waterhouse and Jin, 1987). In Boashan, Lhasa and southern Qiangtang regions, the Permo-Carboniferous sequence contain plant remains, including Glossopteris, Stenophyllum and Dichotonopteris of the Gondwana affinity indicating that Tibet was part of Gondwanic India during Permo-Carboniferous times (Xiaochi, 2002). The evidence for a submarine rift related to the detachment of the Lhasa Terrane from Great Gondwanaland (Chang Chengfa, et al., 1986) is therefore doubtful. There are several other reports of common faunal forms with distinct Gondwana affinities from the two sides of the Indus-Tsangpo feature, from Ordovician to Jurassic. On the other hand, in the Triassic a geosynclines seems to have developed in the area covering the two sides of the Indus-Tsangpo feature (Xu Baowen et al., 1984, p.49), and hence the fauna on the two sides was identical. The Gangdise magmatic activity perhaps marked the end of these geosynclines.

Further, it may be pointed out that continuity of paleoclimatic was maintained over the landmass of India and Tibet from the Paleozoic through Cenozoic eras and up to the Pleistocene Epoch. Palynofloral data from intra-trap sediments of the Dras Volcanic Complex in Ladakh indicates that Kutch in western India and the Ladakh area had a tropical to subtropical climate during the late CretaceousPaleocene (Mathur and Jain, 1980); climatic similarity prevailed even in the Middle Pleistocene. Vertebrate fossils from the Hundes basin of Tibet including Panthelop, Bos, Equus, Rhinoceros, Hipparion and Hippopotamus, reveal an affinity with the Upper Siwalik fauna and indicate that at least in the Mid-Pleistocene the Tibetan land was only about 1000-2000m, possibly less, enjoyed a warm and moist climate with tropical to sub-tropical forests (Norin, 1946).

The above paleontological evidences therefore imply that India remained intact with the northern continents, perhaps, from, Precambrian. Since, it had been an integral part of Great Gondwanaland as well; the latter could not have been an independent landmass. Xiao Xuchang (1980, p. 167) insisted that "The Permo-Carboniferous deposits occurring on both sides of Yarlu-Zhangbo river may be regarded as forming part of a single platform domain". Zhang Haixiang (1984) specified that "the available data indicate that the Yarlu-belt is not entitled to be a suture zone", and that "both sides of the Yarlu-belt 
belong to unified sedimentary basin from Triassic to the Cretaceous". Wang Naiwen (1984) emphasized that "it is unbelievable that the Yarlu-Zhangbo Indus belt is the suture between the southern and northern continents".

\section{Volcanic History, Structural and Paleomagnetic Evidences}

\subsection{Volcanic History}

The ITSZ ophiolites are emplaced in two independent episodes differing in physical and chemical characters (Bao Peishing and Wang Xibin, 1984). They are suggestive of Late Jurassic-Early Cretaceous and a little younger again in Early Cretaceous. Thus, $\mathrm{U} / \mathrm{Pb}$ determination from Xigaze provided an age of $119 \pm 25 \mathrm{Ma}$ from the southern whereas $80 \mathrm{Ma}$ from garnet amphibolites was given for the northern ophiolites and the two are quite different with those of the mid-oceanic ridge basalts (Bao Peishing and Wang Xibin, 1984). It implies that the two obviously tapped at different levels of the mantle and is certainly not obducted ocean floor material. It would further suggest that the magma emplacement started about 100 Ma before the presumed suturing. In the face of this evidence Girardeau et al., (1984) have no hesitation in asserting "the ophiolites was obducted during the Eocene', just because it fits in with the modern global tectonic concept. The two emplacements are confined within two faults dipping at $60^{\circ}$ towards the inside of the rift valley they have formed (Tapponnier et al., 1981, p. 408). The geophysical studies (Xiong Shaobi et al. 1984) have shown that the area to the north of the suture zone has risen, whereas that to the south has subsided, and the activity produced a deep trench in between.

Among several volcanic episodes from the Precambrian to the Tertiary, the three most widespread episodes in the Indian shield are Rajmahal, Deccan Traps and Dras Volcanic Complex in mobile belt of Ladakh. It is interesting to note that the Dras Volcanic Complex is coeval with the Deccan basalts. Proponents of the plate tectonics hypothesis suggest that the Rajmahal Trap originated from Kerguelen mantle plume (Pierce, 1978) and the Deccan Trap from Reunion (Morgan, 1972) while India passed over these hot spots during its northward drift (Figure 2). Moreover, Saxsena (1986) indicated that the time range of outpourings of these traps (Rajmahal 170-100 Ma, Deccan 113-31 Ma) far outlives the supposed time of collision of plates and drift (60-50 Ma). Secondly, the age of Deccan flows should be older northwards and degree of differentiation should increase southwards if they resulted from India's northward drift, but just the opposite has happened. The distribution of major and trace elements in the Deccan Trap indicate magma of intra-crustal origin and not a mantle plume (Pandey and Negi, 1987).

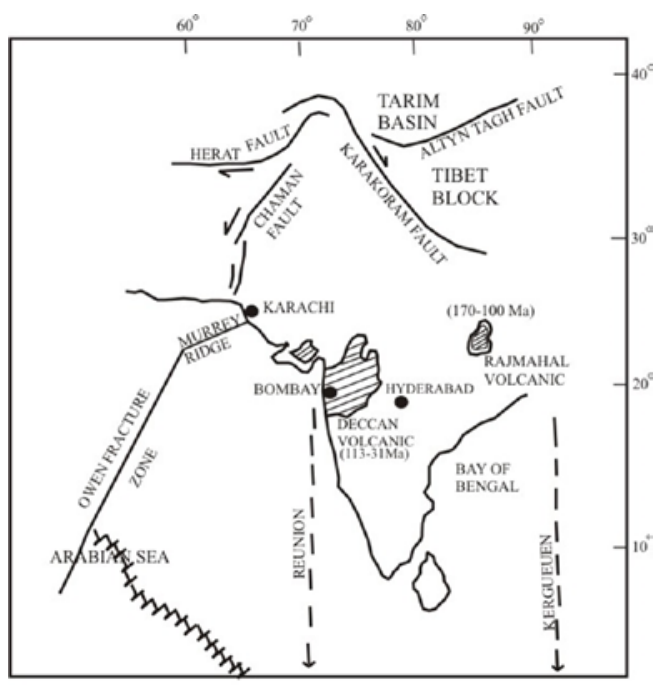

Figure 2. Positions of hotspots and adjacent geodynamical active regions (after Sinha, 1992).

According to the plate tectonics, volcanism of island arcs resulted from partial melting of the down going slabs of oceanic lithosphere, yet the Indus- Yarlu-Tsangpo Suture (IYTS), which has gone thousands of kilometers of oceanic crust, no partial melting seems to have taken place, and consequently, 
no volcanoes exist in the Tibet area. There were a few volcanoes associated with the rift valleys, but all are dormant presently. Incidentally, their association with the rift valleys in Tibet, as in Africa suggests a tensional feature. Briden (1976, p. 415) admitted that "geological evidence of subduction is selfdestructive on plate tectonic reasoning". The Indian plate, drifting from the southern hemisphere, is believed to have included the Assam area. However, the Indus-Tsangpo Suture Zone (ITSZ) is not continuous all around the erstwhile Greater India. Thus, eastward of the area north of Myanmar it does not exist (Beloussov et al., 1979). Its place is taken by wide band of Jurassic phyllites, intruded by granites at Rinbun, southwest of Lhasa, and north of Myanmar in Jurassic phyllites intruded by Tertiary granites (Figure1). There is no trace of the suture east of this point. It is surprising that the Lhasa Block carried typical glacial deposits and typical Gondwana flora overlying metamorphic basement (Tapponnier et al., 1981; Upadhyay et al., 1999; Sinha, 2002), and it would be difficult to explain if the Indus-Tsangpo Suture zone is to be treated as suture zone. The Indian plate, as per the plate tectonic speculations, ought to have been near Madagascar during the Cretaceous, and yet the margin of this plate has been extensively affected by thermal metamorphism, produced by magma emplacement and the southern margin of the Lhasa plate is similarly affected. Nicolas et al., (1981) agreed that the ophiolites at the contact shows chilled margins and also pointed out that" low temperature plastic flow structures have not been described from the ophiolites', whereas those developed under fluid conditions abounds. It is therefore that the ophiolites are not formed of obducted ocean floor.

The second magma, the Early Cretaceous emplacement, occupies the northern half of the so-called suture zone. Minerals present in the ophiolites include diamonds, moissanite, enstanite etc, indicating that the magma originated at a temperature of $1105-1240^{\circ} \mathrm{C}$, a pressure of $27-46 \mathrm{~kb}$, and to a depth of 80-140 km (Liang Rixuan and Ban Wanji, 1984). Xenoliths of country rocks are common and confirm that the magma was in a highly fluid state. The bulk of the ophiolites are essentially represented by a mantle sequence which comprises harzburgite, dunites and chromitites. Significantly, holocrystalline chromitites are often pisolitic and host a variety of ultra-high pressure minerals (UHPM), as well as, native metal and PGE alloys (Bai et al., 2003; Robinson, 2004). Crystal settling in the second emplacement is extensive and has resulted in acidic rocks at the top and ultrabasic, including cumulate gabbros and peridotites, near the bottom of every exposure."The sequence is often underlain by harzburgite tectonites, with fragment veins of rodingites. In addition, a dyke complex has been recognized. Dykes and sills having chilled margin abound, whereas, sills cut through sills and dykes cut through dykes. Had there been formed of oceanic crust, obducted in the process of continental collision, there would not have been two separate emplacements, nor would they differ to this extent in their physical and chemical characteristics, and certainly would they not have suggested high temperatures and pressures in the region of their origin. These features unequivocally refute the obducted oceanic crust concept.

Moreover, the time-space distribution of supposedly post-collision (i.e., post-Eocene) magmatic activity does not support whole sole under plating of the Tibetan plateau by Indian lithosphere because there is no evidence of extensive magmatic activity over the plateau during the last 40 Ma. Majority of the volcanic episodes are of Pliocene-Recent age, bear a mantle signature and occur on either side of the Jinsha suture in northwest Tibet. According to Harris et al., (1988) volcanic rocks and isotope geochemistry indicate progressively younger periods of volcanism and intrusive magmatism from north to south.

The modern global tectonic concept advocates that the Indian plate has been underthrusting the Lhasa plate since the collision in the Eocene-Miocene and as a consequence the latter has been uplifted. However, the Tibetan plateau in the latest Pliocene had a subtropical climate and was only about a thousand meters in altitude. The uplift to $4000 \mathrm{~m}$ or more took place beginning in the Pleistocene (Han Tongling, 1984, p. 75), and may be genetically related to the widespread normal faulting over the Tibetan plateau in the Quaternary. Based on geophysical observations, Cui Zhuozhou (1984) confirmed that although the crust over the Tibetan plateau is twice the thickness of the normal continental crust, there is no evidence of "twin layer crustal structure', i.e. a crustal block does not underlie another. Significant also is the fact that the $70 \mathrm{~km}$ crustal thickness continues "at least to the High Himalayan chain", (Lepine et al., 1984) i.e. well to the south of the Indus-Tsangpo feature, and underthrusting by the Indian plate cannot be invoked to explain the phenomenon. Raiverman (1992, p. 139) stated that "subduction (convergence) of the Indian plate is not likely mechanism for doubling of thickness". 
Beginning at the northern margin of the Himalayan range the thickness of the crust decreases progressively southward. This area constituted the fluctuating margin of the Tethys and with such a vast sea in central Asia the drainage in the emergent area of central India must have been northwards for a large part of Earth history. Sediments in the Himalayan area often suggest a source area in the south. Zhang Changzhou and Wu Shizhi (1984) opined that "the reason why the plateau has become the 'roof of the world' is certainly not the horizontal compression from the north to south, but, instead, is a result of vertical uplift that accompanied the second and third episodes of the Himalayan uplift from Oligocene to post-Pliocene. Cui Zhuozhou (1984, p. 137) agreed that uplift has taken place in the Miocene-Pliocene, accompanying the extensive faulting over the plateau. Raiverman (1992, p. 148) suggested that the Tibetan plateau with their gigantic height was an event of very short duration, sometime between the late Pleistocene and Holocene.

\section{$4.2 \quad$ Structure}

Several studies have shown that the structural grains of Peninsula India extend up to the Lesser Himalaya (Auden, 1935; Valdiya, 1976, 1988; Raiverman, 2002). Indeed, the pre-existing crosslineaments within the ophiolites of the Indus-Tsangpo Suture Zone of southern Tibet showing same concept are carried into the higher and Tethyan Himalaya, and up to trans-Himalaya (Gansser, 1980). The Suru lineament, a major north-south Trans-Asiatic lineament, extends from the Punjab plains in India to the arctic Ocean, running close to the $60^{\circ} \mathrm{E}$ meridian, and has been divided into eight segments (see: Raiverman, 1992, 123)). Segment 2, falls within the central and Tibetan Himalaya and follow the Suru River in Ladakh. It demarcates the axis of culmination between Kashmir and Chamba synclinorium and also another within the Zaskar synclinorium. Raiverman and Misra (1975) recorded evidence of the extension of the North-South trending Suru tectonic axis (lineament) across the IndusTsangpo Suture Zone in Ladakh. The deep seismic profile (DSS) between Pamir and Kashmir (Kaila and HariNarian, 1981; Beloussov et al., 1980) suggested that there is neither suture at the 'IndusTsangpo Suture Zone' nor any subduction of the Indian plate below the Tibetan. It is significant that the geometrical pattern of trans-Asiatic lineaments (Raiverman, 1992, fig.4) shows their continuity with those in the Eurasian block, as revealed in the spatial distribution pattern of the orographic axes of Eurasia (Figure 3). These lineaments are the lines of geodynamics activity which have had a close knithistory from the very early stages of geologic time (Beloussov, 1962). Had the Indian plate moved over the earth's surface for thousands of kilometers, involving even rotary motions before its collision with the Asian plate, such a perfect fit of so many lineaments would not have been possible. Long-distance orogenic movements for the Indian plate cannot be taken for granted based on such features as lowangle thrusts in the Himalaya or fossil oceanic crust in the suture zones.

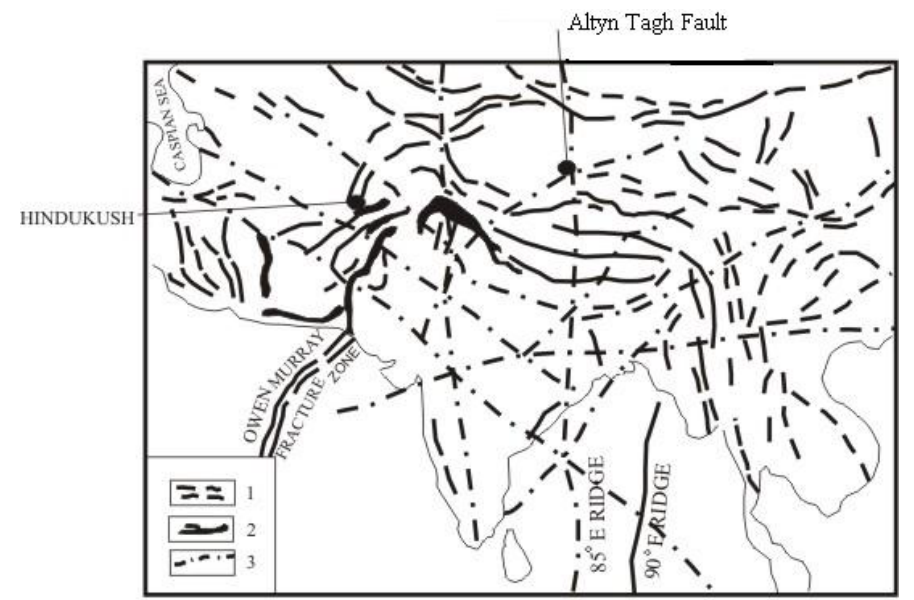

Figure 3. Trans-Asiatic lineaments and orographic axes in Indian Peninsula, Himalaya and Central Asia. Note the correspondence between the trans-Asiatic lineaments and the disposition of the orographic axes (after Raiverman, 1992).1-Orographic axis; 2-Ophiolite; 3-Lineament. 


\subsection{Paleomagnetism}

In the paleomagnetic interpretation, India is believed to have migrated from southern hemisphere from about 60-70 Ma to $20 \mathrm{Ma}$ (see: Qureshy, 2004, for references therein). If the Tethys was epicontinental is accepted as discussed elsewhere, it would follow that India has not migrated from the southern hemisphere, as often suggested on paleomagnetic evidence and instead, it has always been where it is except for a counter clockwise rotation, beginning around $65 \mathrm{Ma}$, when Carlsberg Ridge came into being. The voluminous outpourings of Deccan lavas were erupted, and the peninsula in its lower part was pushed eastward. Evidence based on disjuncts does not support a position for India besides South Africa, and the above paleontological evidence clinches the issue finally. Indeed, this discrepancy between the paleomagnetic evidence and other lines of evidences has been concern to many, but it could clearly be a result of polar wandering sensu stricto, and if so, it should have been present in the African data as well. Klootwijk (1979, p. 68) recognizes that paleomagnetic data are not available from the Early Tertiary of Africa and South America, and this deprives the Indian data of being checked and verified. It is possible under the circumstances that as the South Pole migrated to its present location, India having recorded the event unequivocally appeared to have migrated to the north, and the prevailing views about the origin of the Himalayas in terms of the modern global tectonics and suturing was accepted. Klootwijk (1979, p. 71) agrees the evidences discussed by Gansser (1977) record tectonic phases in the IndusTsangpo Suture Zone (ITSZ) area that preceded the suggested collision. Also, in support of this is the fact that orogenic activity in the Himalayas had started in the Cretaceous, and major phase had occurred in the Eocene, i.e. the tectonic activity was undoubtedly earlier than the supposed collision and no explanation has been offered for this anomaly. And if the Himalayas have not originated as a result of continental collision or plate tectonics and subduction or even in geosynclines the explanation for their genesis must be looked for elsewhere. The Himalayas could, then, have been borne by vertical uplift and gravity gliding. McElhinny (1970) thought that in the Eocene India was still at the equator whereas Le Pichon (1968) placed India $1000 \mathrm{~km}$ away from the then border of Eurasia in the upper Eocene, and, accordingly envisaged this much of shortening in the Himalayas. However, if India migrated at an average rate of $5 \mathrm{~cm} /$ year it must have travelled this distance in about $20 \mathrm{Ma}$ and then only the collision must have taken place, perhaps in the Oligocene. Whatever shortening, if any, has taken place in the Himalayas must have been subsequent to this collision.

The maximum width of the Tethys, along the western Pacific, was about of the order of 6000-7000 $\mathrm{km}$, and the width of the ocean north of India may be put around $4000 \mathrm{~km}$ in the west and $5000 \mathrm{~km}$ in the east, north of Assam. The Indian plate beyond the Greater Indian continental crust must have consisted of oceanic crust. All this ocean crust minus the part to the south of the Angaraland must, then, have been subducted into the Indus-Tsangpo Suture Zone (ITSZ). This part on the Indian plate is variously estimated at around $1500 \mathrm{~km}$. What happened to the balance crust and how did the Angara continent arrive at the site remain unexplained.

\section{$5 \quad$ Tension and Shortening over Tibetan Plate}

Tapponnier et al., (1981, p. 408-413) ruled out any compressional feature and emphasized the importance of east-west extensional tectonics in northern Tibet in the Quaternary (Figure 4). Indeed, the rifts and faults in the given area are currently active and do not cut across IYT feature, but are marked by considerably intense uplift in the region. In the south the rifts enter the Himalayan belt, implying the tension in the area. The extensive Xidatan Fault clearly indicates evidence of a tensional state in its normal and strike slip faulting."The large scale tension and steep sides of the tension gashes imply that a large earthquake occurred along this fault in the past few hundred years" (Chang Chengfa et al., 1986, p. 507). The presence of normal faults and rift valleys in central and southern Tibet further contradict the views on the existence of north-south shortening in Tibet' (Segnor, 1987; p. 404). Such hypothetical shortening, resulted by underthrusting of the Indian plate is one of inspirations for the collision under plate tectonics. According to Patriat and Achache (1984, p.620) it amounts to $1900 \pm 850$ $\mathrm{km}$ of shortening with in Eurasia since the collision, plus $700 \pm 300 \mathrm{~km}$ of convergence between India and southern Tibet. Thus, the total north-south shortening resulting from the collision between India and Eurasia amounts to $2600 \pm 900 \mathrm{~km}$ (Patriat and Achache, 1984), which apparently seems to be more than the distance from Cape Cameron to Delhi. 


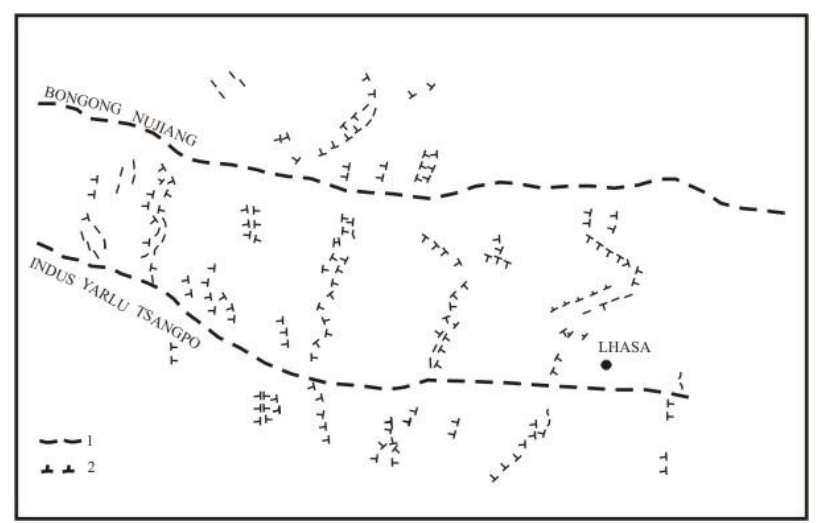

Figure 4. Quaternary faulting covers practically the entire Tibetan plateau. Active rift valleys and normal faults bespeak of tension over the entire area. I-Indus-Yarlu-Tsangpo Suture and II-Bongong-Nujiang Suture.

Tapponnier et al., (1981, p. 414) confirm that a number of north-south rift valleys and normal faults have been developed on the Tibetan plateau and fault zone solution confirm extensional tectonics (tension) all over the area, and not compression, that one would expect from subduction/collision zone. The only existence on compression found by Tapponnier et al., (1981) over the Tibetan plateau was some mild folding in the Cretaceous i.e. long before collision and suturing. Owen (1976, p. 269) consider that ophiolites could be siamatic outpouring, brought up by deep seated faults. Similarly Steward (1982) opined that occurrence of tholeiitic basalts near the bottom of the sedimentary sequence suggests volcanic activity related to thinning and rifting of the crust. Dickins (1994, Fig. 3) have summarized the structural development of this region during Permian and Triassic. No evidence has been found for folding or collision (plate tectonic terminology) during the Lower Permian but voluminous basaltic eruption has been interpreted as caused by rifting or oceanic spreading (see Gaetani et al., 1990). And according to Dickins (2001, p. 132), this could as alternatively be explained, however, by widespread crustal tension without rifting or oceanic opening strengthen our conclusion discuss above.

The other constraint in progressive underthrusting of the Indian plate below is that for a $30-35 \mathrm{~km}$ thick plate to get smoothly underthrust without even an occasional tremor along the so called suture zone or somewhere below the Tibetan plateau, particularly so as the uneven bottom of the plate at the Moho. Qureshy and Warsi (1981, p. 217) examined the isostatic gravity anomaly of the Himalayan belt and noted that a "high is a typical feature which runs north of the Main Boundary Fault (MBF) all along the Himalayas", and attributed it to a possible thickening of the basaltic layer underneath. Also, it is significant that gravity studies indicate the thickness of the continental crust south of the main range to be of the order of about $80 \mathrm{~km}$, and earthquakes seem to correspond with this down bulging, rather than with the sub-ducting model. This is entirely in- compatible with the collision model or the subduction concept. Dewey and Bird (1970, p. 626) and Gilluly (1971, p. 2388) wondered that "despite this being the region of greatest tectonic activity on the earth, there has been no sign of magmatic activity along the Himalayas" and accordingly concluded that "the tectonics was assuredly not all related to plate motion and neither to magmatism". Qureshy and Warsi (1981, p.221) stated that "a number of geologic factors seem to cast doubt on the existence of a subduction zone along the IndusTsangpo suture, so did the satellite and terrestrial gravity data". Even the force needed for this activity ought to be far more than that needed for the presumed plate movement, and cannot be envisaged. Plate tectonic model of India-Tibet collision and subsequent subduction (convergence) and crustal thickening along the Indus-Tsangpo suture (ITSZ) cannot be explained by the subduction of Indian plate as the lighter continental crust cannot subduct (McKenzie, 1964). Moreover, even the supposedly oceanic crust of the Tethys could not do so. In addition to thickness the subduction would require a low-angle movement of one plate below another for a distance of more than $1000 \mathrm{~km}$, whereas subduction is purportedly a 'high angle' process. In this context, it is important to mention that Indian plate could not possibly cut across the $8-20 \mathrm{~km}$ thick ophiolites wall that formed at the time of the supposed collision of the two plates, to be able to underthrust the Tibetan plate (Ahmad, 1989). Similarly, the continuity of Quaternary faults from the Tibetan plate up to the Indian plate, south of 
the suture suggest that no underthrusting is in progress because the faults on the Indian plate have their continuity with those on the Tibetan plate.

One cannot but agree, with Dewey et al., (1989) who based on data from Tibet, the Himalayas and China, discussed arguments for and against the underthrusting of greater India beneath Eurasia (Zhao and Morgan, 1987), crustal shortening and thickening (Dewey et al., 1988) and eastwards lateral extrusion (Tapponnier et al., 1986) models for the northwards motion of India with Eurasia and concluded that models advocating underthrusting and lateral extrusion were untenable. And this, incidentally, means that the Himalayas has not been formed as result of compression or even subjected to compression, as often suggested, except for that caused by the oroclinal rotation.

\section{Discussions}

The Tibetan glacial deposits suggest a large ice cap covering larger part of Gondwanaland, as envisaged by Alex Du Toit (1937). It does not comply with lowering of the temperature over the Earth as the Europe and North America were having a warm tropical climate. Moreover, even such abnormally large ice cap could not have deposited glacial debris in parts of Saudi Arabia, Afghanistan and more so in northern Tibet. The only possibility is that the South Pole of the time was located in extreme south of Peninsular India. These glacial carry undoubted Gondwana fauna and flora (Wang Naiwen, 1984; Waterhouse, 1992; Upadhyay et al., 1999). Post-symposium field excursion guide book of Tibet (1984) recorded the glacial deposits containing cold water fauna and suggested that the boundary between Indian plate and Eurasia is somewhere to the north, ruling out the Indus-Yarlu -Tsangpo Suture Zone (IYTS). It seems appropriate that the Tibetan deposits were formed by northward moving ice-bergs evidently under marine conditions in epicontinental environments. The ophiolites emplacements in the Indus-Tsangpo Suture Zone (ITSZ) took place in two phases, Late Jurassic and Early Cretaceous, and subsequently, once again in Early Cretaceous. It implies that the magmatic activity started about 100 Ma before the Eocene-Miocene suturing in the area and is apparently more than the entire span of the Cenozoic Era. The evidence contradicts Girardeau et al., (1984) asserting that "The ophiolites was probably obducted during the Eocene', merely to justify the plate tectonic hypothesis.

The ophiolites are invariably related to collision and therefore represent fallible hall-mark of subduction zone. Yet, in Pakistan Zhob and Muslim Bagh, and in Iran, Oman and Turkey etc. they are invariably Cretaceous in age implying that intrusion or obduction preceded collision by a few million years. Thus, Stoneley (1974, p. 899) admitted that "the ophiolites were emplaced while the Indian continent was presumably still some hundreds of kilometers away from Eurasia". Even, Tapponnier et al., (1981, p. 410) worried that the emplacement of the ophiolites "occurred earlier than at the end of the Eocene, which would place new constraints on speculations based on plate tectonic reconstruction". It is equally intriguing that if the Indian plate did not extend beyond the Chaman Fault zone, in what way the ophiolites of Oman, Iran and Turkey are influenced by this suturing that they behaved similarly. Beloussov (1979, p. 422) wondered that from an ocean several thousand kilometers wide existed from the Paleozoic through Mesozoic, only these few small beads of the pressed out material of the subducted crust were preserved and everywhere they are of the same late Cretaceous age. Crawford (1975, p. 1179) apparently raised an objection that if the Indus-Yarlu Suture Zone (IYSZ) is a relic of oceanic subduction, it lies on the wrong side of the Himalayas. Interestingly, "In many places along the Yarlung-Zhangbo, the ophiolite belt seems to be limited to the north and south by steeply dipping faults and therefore occupy a rift valley, presumably initiated in the Triassic (Stocklin, 1981, p. 122) and continued up to the Cretaceous. The associated deep water sediments justify that the ophiolites are confined in this rift valley. Stocklin (1981) and Raiverman (1992) compared to the Red Sea, which would mean the existence of an oceanic ridge. It is also interesting that the Red Sea rift shows a genetic relation between intracratonic rifts and mid-oceanic ridges in view of the continuity between the Red Sea and the Carlsberg ridge (Figure 5). Indeed, a simple rift valley should not qualify for the "suture" as it dies out at both the ends. 


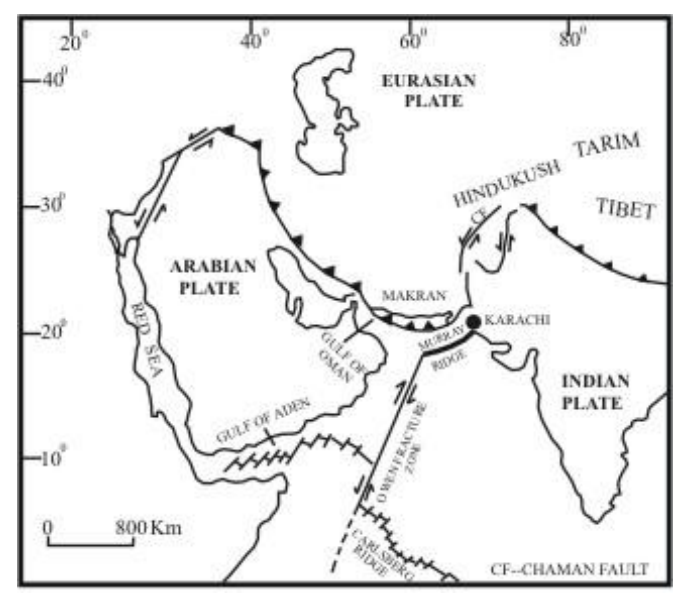

Figure 5. Map showing mid-oceanic ridge system of the Indian Ocean, and rift system of Africa and the Red Sea.

Significant also is the fact that three other so-called suture zones Bongong-Nujiang, JinshajingTungbianhe and Jinsha- Tongbian exist in the Tibetan region, north of Indus-Yarlu-Tsangpo Suture (IYTS). They are identical in character with IYTS, and effusive are similar to those existing along the mid-ocean ridges. And if latter is a rift valley, as discussed elsewhere, all these features, too, may be rift valleys. This leads to the conclusion that a state of tension over the entire Tibetan area manifested itself in narrow belts from Late Paleozoic to Mesozoic. This belt, for some unknown reason, migrated step by step southward. As long as these belts appeared in regions of very thick sediments $(>70 \mathrm{~km}$ or so), the mobilized magma underneath was unable to uplift these, they were torn apart as rift valleys. However, southward, as the activity entered the region of the southern margin of the Tethys, the thickness of the sediments decreased significantly and the magma could force the sediment upward. The uplift resulted in the Himalayan Range in the Tertiary. The Himalayas are, thus, formed of vertical and intrusive magmas and not by the plate motion or subduction/collision, as popularly believed today (Valdiya, 2015; references therein). What caused this vertical uplift is not altogether clear but it could be the progressive downwraping of the Indo-gangetic basin, resulting in the migration of the sub-crustal material to the adjacent belts on the two sides, Himalayas on the one hand and the Assam plateau and Vindhyan and Aravallis ranges rising co-genetically, on the other. Thus, Crawford (1974) concluded that the Himalayas were formed inter-continentally along a zone with an Indo-Tibetan unit, whereas Ahmad (1989) support Russian authors in that Himalayas, like the Tien Shan are an epi-platform orogenic belt.

The Paleomagnetic evidence insists that India has migrated from a southern hemisphere to suture with the northern continent, and underthrust the Lhasa block to the extent of about $2000 \mathrm{~km}$ (Klootwijk, 1979). Furthermore, the process is still continuing at the rate of $2-3 \mathrm{~cm} /$ year (Armijo et al., 1984; Sinha, 1992) and even 5cm/year (Patriat and Achache, 1984; Klootwijk, 1986). However, even in terms of plate tectonics, a wall of ophiolites, some $8-20 \mathrm{~km}$ thick, is situated in between the two plates at the time of the collision. To underthrust the Tibetan plate, the Indian plate would have to cut across this wall, a simply difficult preposition (Ahmad, 1987). Moreover, if the Indian plate underthrusts the Tibetan plate by about $2000 \mathrm{~km}$, plus about $500 \mathrm{~km}$ of shortening believed to have taken place along the Himalayas (Gansser, 1974), there should be a break of this order along the western margin of the Indian plate, and displacement of the coast along the junction of the Indian and the BaluchistanAfghanistan part of the Asian plate, which is supposed to be along the Chaman Fault. Yet there is no displacement along the supposed junction and the Baluchistan coasts are smooth from one end to the other (Figure.6). Neither the Chaman Fault nor any of its parallel faults cut across the coast, and instead every single fault of the area takes a sharp turn from north-south to east-west implying oroclinal rotation of the Indian plate (Carey, 1955). Indeed, the absence of a displacement along the coast suggests that neither there has been an underthrusting of the Indian plate beneath Tibet, nor any shortening along the Himalaya. Similarly, significant is the fact that the paleomagnetic evidence is based only upon the analysis and interpretation of the Indian rocks, and no supporting data from adjacent continents of Australia and Africa/Antarctica. 


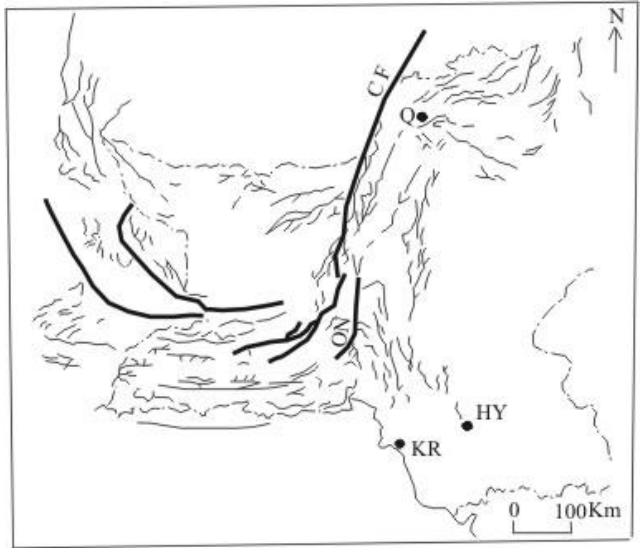

Figure 6. NNE-SSW faulting in Baluchistan; all the faults take a sharp turn to the west and not a single fault cut across the coast (after Quittmeyer, R.C. Farah, A. Jacob, K.H., 1979); C.F. = Chaman fault; O.N. = Ornach- Nal fault; Q= Quetta; K.R. = Kirthar Range; K= Karachi.

Significantly the thickness of the crust in the Lhasa block is admittedly of the order of about $70 \mathrm{~km}$ (Choudhary and Datta, 1975; Beloussov et al., 1984; Sinha, 2002), and such about twice the normal crustal thickness is explained by the underthrusting of Indian plate. However, it is to be realized that about $70 \mathrm{~km}$ thickness of the crust to the south of the ITSZ, and shows thinning only near the northern border of the Himalayas. Hirn et al., (1984) admitted that "such a large thickness was unexpected so near to the High Himalayas". It is of the same order in the Pamir's and about $60 \mathrm{~km}$ in the Andes. Yet, these cases are not interpreted due to underthrusting phenomena. Hirn et al., (1984) confirmed that there is no evidence to support the gravity based conclusion that the Indian crust underlies the Tibetan crust above a smoothly depressed Moho. Chang Chengfa et al., (1986, p. 301) however, believed that the crustal thickness of the Tibetan plateau is to be explained by distributed shortening within the Tibetan crust, and do not support the long distance underthrusting of the Tibetan plateau by the Indian continental crust. However, it is not a very suitable explanation either and almost perfect uniformity of the thickness bespeaks against the suggested mechanism. The unique thickness of the crust was perhaps the consequence of a quiet, progressive down-warping of the basin from the Ordovician to Triassic or may be Cretaceous. The beds remained undisturbed and an immense thickness accumulated over the vast area covering the whole of Tibet and parts of India and China.

The nature and structure of the ITSZ remain an open question as yet. It has been suggested that the Ordovician to Permian faunas and floras of northern Tibet were of Gondwana affinities (Xiao Xuchang, 1980; Chen Guoming, 1984), and that in the Precambrian and Paleozoic the "Tibetan plateau was a part of Gondwanaland". Wang Naiwen (1984) insisted that "it is unbelievable that the YarlungZhangbo is the suture between the north and south continents". Guo Tieying (1984) stated that the "Indian platform extended northward, so also the glacio-marine deposition and the cool water fauna" Zheng Haixiang (1984) stated that "the Y-belt is by no means such a boundary, land instead existed as a broad transitional zone of paleontology as well as lithology to connect the so-called southern and northern continents". He reiterated that "both sides of the Y-belt belong to the same tectonic system; the strata across the Y-belt constitutes an almost continuous section from Triassic to Cretaceous". Lin Baoyu and Qui Hongrong (1984) agreed, and so also Owen (1976) on the basis of detailed study of seafloor spreading.

On the contrary, available evidences suggest that the Indus-Tsangpo feature represents a rift valley. Wang Xibin et al., (1980) and Stocklin (1981) concluded that the so called Indus Suture zone is a tensional feature. Chang Chengfa (1980) stated that the late Permian-Triassic rifting which resulted in the Panjal Traps produced the Indus-Tsangpo feature. Gopel et al., (1984) agreed that it is a propagating ridge, under a slow spreading condition i.e. it was not a suture. Chang Chengfa(1986) contradicted that the Indus-Tsangpo Suture is "the northern limit of the exposure of the Indian continental crust", but the similarities in faunal assemblages of glacio-marine deposits of India and northern Tibet "indicate the Gondwana origin of the Lhasa terrane", which lies entirely to the north of 
the ITSZ. The Indian plate should have extended to this area, and may be to the Tein Shan Range and to the rest of Asia. Similarly, the occurrence of Gigantopteris flora in northern Tibet confirms warm climate, whereas the cold climate Glossopteris could not have survived in the area. The warm climate flora migrated from adjacent China, whereas adjacent northern India was still having a cold climate. The anomaly is that the warm and cold climates existed so close to each other - a near impossible situation on a globe of present diameter, as if the temperate region did not exist!

The evidence at hand suggests that a rift valley developed in the area in Triassic, and continued to deepen progressively. The presence of Triassic basalt flows northwest of Lhasa (Chang Chengfa et al., 1986), the ophiolites of Jinshajiang-Tangtianhua, the geosynclinals activity in the Nagui-Yangbajang area, and Nujiang-Bongong rift system of late Permian provide evidence of co-genetic widespread tensional activity over the whole of Tibet in late Permian and early Triassic. Marine conditions already existed in the area, and within the rift valley the sea continued to deepen. During the magmatic emplacements in the Jurassic and Cretaceous, the rift valley fill was thrown up to form mélange. Had the Indian plate been underthrusting the Tibetan plate, the earthquakes would have been common over the plateau and frequent along the suture zone, but there is no recorded seismic activity along it. There may be a possibility of the northward movement of the North Pole instead of the Indian Plate as suggested on paleomagnetic data derived from Indian rocks. Wesson (1974) insisted that the paleomagnetic evidence should be viewed in the light of polar wandering, involving movement of the magnetic field without movement of space of the planet's surface feature. It would, thus, seem possible that the Tethys was an epicontinental sea, and in the south extended up to Lower Himalayas, as indicated by the Eocene fauna near Nainital, and the Permian fauna at a number of places in Lower and Middle Himalayas. It is also more likely that this sea extended occasionally to the Gangetic basin.

The evidence is, thus, the northern Tibet, and the northern continents - Cathaysia, Angaraland and Laurasia - were never separated from the Indian-African continents, and so as the entire Gondwanaland. (Chang Chengfa et al., 1986) stated that "it is not yet possible in much of the Lhasa continental fragment to separate structures formed before and after the beginning of the Indian-Asian collision". On the other hand, the Indian Peninsula, admittedly, has undergone a counter clockwise rotation, creating the Arabian Sea, and separating Karachi from the southeastern tip of Oman in southern Arabia. Thus, a single continent, Pangaea, existed till it fragmented into the existing continents beginning in the Eocene, or a little earlier. In view of the above evidence it may be suggested that "The Lhasa Block is a Cathaysia Block, and not necessarily of Gondwana origin. Significantly, both deep earthquakes and many active faults have been recorded from the Himalayan region, nor the Indus-Tsangpo Suture Zone (ITSZ), whereas Tibet is only mildly seismic with well scattered activity, mostly associated with recent normal/ wrench faults (Figure 7). Kaila and HariNarian (1981) analyzed ten earthquakes covering entire length of the Himalayas and noted that the seismic plane progressively became steeper from about $30^{\circ}$ in Assam to about $70^{\circ}$ in Pamir area. There is no evidence of a progressive deepening of the earthquakes foci with the plunging crust. Deep seismic soundings (DSS) (Beloussov et al., 1980) have suggested that all the faults in the Pamir-Kashmir region are nearly vertical. Similarly, Bird and Nafi Toksoz (1977) studied six earthquakes in the Tibetan region and concluded that the lower-most part was molten and the "The inferred high temperature of the Moho is inconsistent with crustal thrusting model for the formation of Tibet". Most of the focal mechanisms found are normal faults in the central part and thrust faults in the peripheral region. The Bouguer anomaly profile across the Himalaya and Tibet suggests a tightly folded upper crust and anomalous material in the core (Wen-Lin et al., 1981). Thus available evidence does not support suturing and underthrusting. 


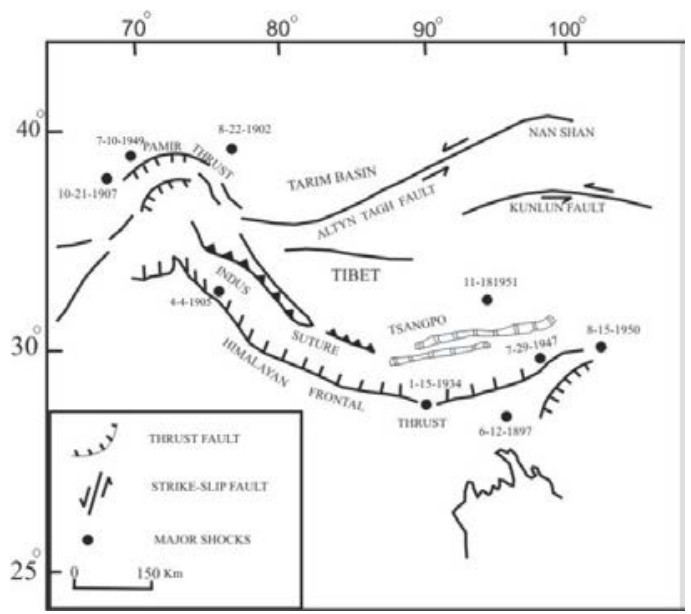

Figure 7. Map of the Himalaya-Kun-Lun region showing features of major tectonic events from 1862 to 1967 (after Chen and Molnar, 1977)

Apart from collisional and suturing origin, it seems that the Earth was of a considerably smaller diameter earlier in its history as indicated by the polar positions in the Permian and the Cambrian (Ahmad, 1989). Based on these, the Upper Permian North Pole was in Verkhoyansk (upper basin of R. Kolyma) and the South Pole was to the southeast of South Africa. The diameter of the Earth at that time would be therefore 55-58\% of the present diameter, based on the adopted Paleomagnetic pole path (Figure 8). Similarly, the Cambrian South Pole was to the northwest of Africa, or just inside the coast and the North Pole was in the Indian Ocean (which did not exist at that time) to the southwest of the then location of Tasmania with Western Australia adjacent to the east coast of Peninsular India yielding a diameter of $50 \%$ of the present. Paleodiameters of the post-Permian geological periods therefore increases progressively from the then to their present locations implying earth expansion. More important, the question of Earth expansion finally resolved by the current NASA intercontinental chord measurements. On the data so far published by NASA the rate of increase of Earth radius comes out at $2.4 \pm 0.8 \mathrm{~cm} /$ year. This rate of radius increase accounts for all ocean floor growth since early Cretaceous without any subduction at all (see also: Carey, 1986).

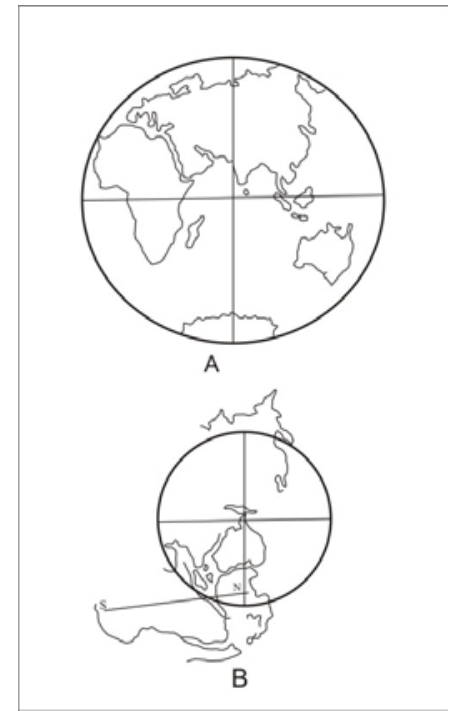

Figure 8. A. Continents on present day globe. B. Pangaea on Permian globe. Note the position of North Pole in eastern Siberia and South Pole in Antarctica; N-S; polar position diameter in Cambrian. 
Pangaea assemblies on a globe of present diameter invariably result in a wide gulf on its east coast, tapering to a point in the region of the Black Sea, or farther west. Yet the paleogeographic studies of the region indicate that no such gulf existed in the past (Ahmad, 1981).However, Carey (1983) has demonstrated that if the continents are assembled on a globe of a smaller diameter the unwanted gulf disappears. This strengthens the above line of evidence, and seems to confirm that the Earth was, indeed, of a smaller diameter and has increased progressively.

\section{Conclusions}

Plate Tectonic model visualizes that the Indian subcontinent was with the northern hemisphere till late Carboniferous and there after drifted to a southern hemisphere close to Madagascar. However, the evidences discussed above lead to the following conclusions:

1. The occurrence of the glacial deposits in northern Tibet suggests that India and Tibet, and hence perhaps all the continents, were together in the Permo-Carboniferous.

2. The presence of vertebrate fauna in Kashmir with European affinities indicates that India and the northern continents were not separated even by a narrow intervening ocean and perhaps were still together.

3. The presence of the well-known Lystrosaurus fauna in Antarctica, South and East Africa and India on the one hand, and Sinkiang, Shansi and Korea on the other, shows that the northern continents and Gondwanaland had either wide land connection in the Triassic or wholly united together at that time.

4. The magma emplacements along the ITSZ is occurred in Late Jurassic to earliest Cretaceous and then again in the Early Cretaceous. The intrusions have thermally metamorphosed the margins of both the Indian and the Tibetan plates implying that these were in their present respective positions and not separated by thousands of $\mathrm{km}$ in the Jurassic and the Cretaceous, and thereafter the Indian plate has admittedly been with the northern continents. Significant at this stage is the development of a eugeosyncline extending from Ladakh to Tibet and affecting both the flanks of the supposed suture zone, confirming that the two plates were together throughout most of the Tertiary.

5. The paleoclimatic continuity was maintained over the landmass of united India and Tibet from Paleozoic through the Cenozoic and up to the Pleistocene.

6. The development of extensive rift valleys and normal faults, cutting across the Indus-Tsangpo Suture Zone shows that even in the Quaternary they were not separated. When was the Indian plate separated from the Tibetan plate? When and how the Indian plate migrated to the southern hemisphere and then returned to its exact original location? In any case, the chances of its return to the exact original location are remote.

7. Also significant is the fact that Tibet was traversed by numerous rift valleys and normal faults, and it is also admitted that Tibet is presently under tension. This, finally, rules out continental collision, and it seems that there is no escape from accepting expansion of the Earth.

8. The Himalayas could, then, not have been borne due to continental collision of landmasses as suggested by modern global tectonics or subduction. Instead, they are an inter-platform type mountain range formed by vertical uplift and gravity gliding.

In view of the above, the so-called ITSZ does not justify being a suture in the modern global tectonic model. Moreover, the deep seismic sounding (DSS) between Pamir and Kashmir proves that there is neither suture at the 'Indus Tsangpo Zone' nor any subduction of the Indian plate below Tibetan plate. The ITSZ is, indeed, a rift valley that had come into being in the Triassic, deepened progressively till magmatic emplacements took place along it in the Jurassic-Cretaceous, and then again a little later in the Lower Cretaceous some $100 \mathrm{Ma}$ before the speculated suturing. The two magmas are entirely different from each other in chemical and physical properties, the later one having originated at a depth of 80-140 km. It appears that a vast area in central Asia downwrapped progressively from late Paleozoic to the Tertiary and in the process, accumulated a vast thickness of sediments, estimated to be of the order of $70 \mathrm{~km}$ right up to the Himalayan area. The basin, indeed, extended farther southwards, shallowing rapidly. Thus the Tethys was an epicontinental sea, and not of oceanic character. The 
evidence based on paleomagnetic of the Indian rocks could be a reflection of the rapid northward movement of the North Pole. India and Australia were together till atleast the Mesozoic, yet no supporting evidence has come from that continent for India's movement out and then its return.

The paleodiameters for the Cambrian and the Permian Earth, determined by two independent methods corroborate each other and suggest that it was $50 \%$ in the former and 55-58\% of the present diameter. It would imply not only that the Earth has increased in diameter but that the rate of increase has accelerated. In the post Permian, based on the Paleomagnetic data it appears that the diameter has progressively increased from one geological age to the next. Meservey (1979) concluded that generation of the present configuration of the continents from Pangaea was topologically impossible without Earth expansion, a conclusion recently confirmed by systematic computer modeling. Pangaea, apparently, cannot be assembled without a major gulf appearing on its east coast and tapering down to a point in the region of Black Sea. Yet all paleogeographic studies indicate that no such gulf existed. The gulf, however, disappears if the continents are assembled on a globe of a smaller diameter.

Acknowledgments. We appreciate the reviewers of the Isaac Scientific Publisher for critical reading of the manuscript. We thank the Editor-in-Chief of Geosciences Research (GR) for recommending the publication of this article.

\section{References}

1. Ahmad, F., 1978. Gondwanaland: the concept that failed. Birbal Sahni Memorial Lecture. Birbal Sahni Instt. Paleobotany, Lucknow, pp 1-29

2. Ahmad, F., 1981.Late Paleozoic to Early Mesozoic paleogeography of the Tethys region. In The Expanding Earth Carey, S.W. (Ed). University of Tasmania, Hobart, pp. 131-145.

3. Ahmad, F., 1987. Indus-Tsangpo Suture: Fact or Fiction. In: Shallow Tethys II. McKenzie, K.G. (Ed). A.A. Balkema, Rotterdam, pp. 113-125.

4. Ahmad, F., 1988. Estimate of paleodiameters of the Earth through geological times. Geol. Soc. India, Vol. 31. Pp. 386-397.

5. Allegre, C.J. and 34 others. Structure and evolution of the Himalayan-Tibet orogenic belt. Nature, Vol. 307, pp.17-22.

Armijo, R., 1984. Quaternary extension of the Tibet plateau- field observations and tectonic implications. Inter. Symp. Geol. Himalaya, pp. 2, 17 (abstract).

6. Auden, J.B., 1935. Traverses in the Himalaya. Geol. Surv. India, Rec., Vol. 69, pp.123-167.

7. Bai, W., and 8 others. 2000. The PGE and base metal alloys in the podiform chromitites of the Luobusa ophiolite, southern Tibet. Canadian Mineralogists, Vol. 38, pp.585-598.

8. Bally, A.W., and 9 others.1980. A note on the geology of Tibet and adjacent areas: Rep. Amer. Plate tectonic Delegation to the Peoples of Republic of China. U.S. Geol. Soc. Open File, Vol. 80-501. 100.

9. Bao, Peishing and Wang Xibin., 1984. The two suites of volcanic in Yarlu-Zhangbo River ophiolite belt - a discussion on the emplacement mechanism of the ophiolites. Intern. Symp. Geol. Himalaya, Vol. 1, pp.111-112 (abstract).

10. Beloussov, V.V., 1962. Basic problems in Geotectonic. McGraw Hill Book Co., New York. 809.

11. Beloussov, V.V., Ruditch, E.M., and Shapiro, M. N., 1979. International structures and mobilistics reconstructions. Geol. Rundschau, Vol. 68, pp. 393-427.

12. Beloussov, V.V., and 12 others, 1980. Structure of lithosphere along the deep seismic sounding profile: Tien Shan-Pamir's-Karakoram Himalayas. Tectonophysics, Vol. 70, pp.193-221.

13. Beloussov, V.V., and 5 others.1984. Deep structure of central Asia along the Tien-Shan-Pamir Himalayas geotraverses. In: Tectonic of Asia.2 $7^{\text {th }}$ Intern. Geol. Congress, Moscow, Vol. 5, pp.29-39.

14. Bird, P., and Toksoz, M.N., 1977. Strong attenuation of surface waves in Tibet. Nature, Vol. 266, pp.161-165.

15. Briden, J.C., 1976. Application of paleomagnetism to Proterozoic tectonics. Phil. Trans. Royal Soc. London, Ser A 280, pp.405-416.

16. Carey, S.W., 1955. The Orocline concept in Geotectonic: Papers and proceedings of the Royal Society of Tasmania. Vol. 89, pp.255-289. 
17. Carey, S.W., 1983.The necessity for Earth expansion. In: The Expanding Earth- a Symposium. Carey, S.W. (Ed). University Tasmania, Hobart, pp. 367-396.

18. Carey, S.W., 1978. Tethys and his Forebears. In: Shallow Tethys II. A. A. Balkema. 3-30.

19. Chang Chengfa, 1980. Tectonic features and evolution of the Yarlung-Zhangbo suture zone: Tethys oceanic plate and its tectonic development. Report Sino-French Coop. Investigation of the Himalayas. 236-237 (abstract).

20. Chang Chengfa and 5 others. 1986. Preliminary conclusions of the Royal Society and Academia Sinica 1985 Geo-traverse of Tibet. Nature, Vol. 323, pp.501-507.

21. Cheng Guoming, 1984. Zonation of the Xizang (Tibet) - Tethys oceanic plate and its tectonic development. Inter. Symp. Geol. Himalaya Vol.1, pp. 21-22 (abstract).

22. Chen, X., and Rong, J., 1992. Ordovician plate tectonics of China and its neighboring regions: In Webby, B.D., and Laurie. R., (Eds). Global Perspectives on Geology, A. A. Balkema, pp.277-291.

23. Choudhary, S.K., and Datta, A.N., 1975. Crustal thickness in north India and Himalayan region and its geological significance. Bull. Geophysical Research, Vol. 13, pp. 29-37.

24. Crawford, A.R., 1975. A Greater Gondwanaland. Science, Vol.184, pp.1179-1188.

25. Cui Zhuozhou, 1984. Research of formational mechanism of Qinghai-Xizang plateau (Tibet): geological interpretation of results of deep seismic sounding. Inter. Symp. Geol. Himalaya, Vol. 1, pp.136-137(abstract).

26. Dewey, J.F. and Bird, J.M., 1970. Mountain belts and the new global tectonics. Jour. Geophysical Research, Vol.75, pp.2625-2647.

27. Dewey, J.F. Cande, S., and Pitman, W. C., 1989. Tectonic evolution of the Indian/Eurasia Collision Zone. Eclogae Geologicae Helvetian,Vol. 82, pp.717-734.

28. Dewey, J. F., and 4 others. 1989. The tectonic evolution of the Tibetan plateau. Phil. Trans. Royal Soc. London, A327, pp.379-413.

29. Dickins, M., 1994. What is Pangaea? In Embry, A. Beauchamp, B., and Glass, D. J., (Eds). Pangaea: Mem. Global Environments and Resources. Canadian Society of Petroleum Geologists. Vol.17, pp.67-80.

30. Dickins, M., 2001. Tethys and the relationship of Southeast Asia and Gondwanaland in the Lower Permian. Contrib. to Geology and Paleontology of Gondwana. Cologne, pp.127-135

31. DuToit, A.L., 1937. Our Wandering Continents. Oliver and Boyd, Edinburg. 377.

32. Fan Yingnian, 1984. Division of zoogeographical provinces by Permo-Carboniferous corals in Xizang (Tibet). Intern. Symp. Geol. Himalaya, Vol. 1, pp.1-2 (abstract).

33. Gansser, A., 1974. The ophiolite mélange: a worldwide problem in Tethyan example. Eclogae Geologicae Helvetian, Vol. 67, pp.419-507.

34. Gansser, A., 1977. The great suture between Himalaya and Tibet: A preliminary account. Eclogae Geologicae Helvetian, Vol. 70, pp.181-191.

35. Gansser, A., 1980. The significance of the Himalayan Suture Zone. Tectonophysics, Vol.62, pp. 37-52.

36. Gaetani, M., Garzanti, E., and Tintori, A., 1990. Permo-carboniferous stratigraphy in SE Zanskar and NW Lahul (NW Himalaya, India). Eclogae Geologicae Helvetian, Vol.83, pp.143-161.

37. Gilluly, J. 1971. Plate tectonics and magmatic evolution. Bull. Geol. Soc. America, Vol.82, pp.2383-2396.

38. Girardeau, J., Mercier, J.C.C. and Zhao, Y.G., 1984. Tectonic and petrology of the Dongqiao ophiolites and Xainxa ultramafic rocks. Intern. Symp. Geol. Himalaya, pp. 2, 20 (abstract).

39. Gopel, C., Allegre, C.J., Xu, R.H., 1984. Constraints on the origin of two Tibet ophiolites from Pb-isotopes. Intern. Symp. Geol. Himalaya, Vol.2, pp.2 (abstract).

40. Guo Tieying et al., 1984. Crustal evolution of Qinghai-Xizang (Tibet) region. Intern. Symp. Geol. Himalaya, Vol.2, pp.80 (abstract).

41. Han Tongling, 1984. On the Himalayan movement and the Qinghai-Xizang (Tibet) plateau movement. Intern. Symp. Geol. Himalaya, Vol. 1, pp.74-75 (abstract).

42. Han Tongling, and Wan Naiwen, 1983.Carboniferous glacial deposits in northern Xizang. Chinese Acad. Science, Bull., Vol.7, pp.41-50.

43. Harris, N.B.W., and 4 others.1988. The geological evolution of Tibet. Report Royal Society Academia Sinica, pp.263-285.

44. Hirn, A., and 11 others. 1984. Crustal structure and variability of the Himalayan border of Tibet. Nature, Vol.307, pp.23-25. 
45. Kaila, K.L., and Narain, H., 1981. Evolution of the Himalaya based on seismo-tectonics and deep seismic sounding. Geol. Surv. India. Misc. Publ. Vol. 41, pp. 1-40.

46. Klootwijk, C.T., 1979. A review of paleomagnetic data from the Indo-Pakistan fragment of Gondwanaland. In. Geodynamics of Pakistan, Farah, A. and DeJong, K.A., (Eds). Geol. Surv. Pakistan, pp.41-80.

47. Klootwijk, C.T., 1986. Greater India's northern margin: Paleomagnetic evidence of large scale continental subduction. In Shallow Tethys II, McKenzie, K.G. (Ed). Balkema, Rotterdam, 529.

48. Lepin, J.C., 1984. Explosion seismic sounding beneath and south of the High Himalayas. Intern. Symp. Geol. Himalaya, Vol.2, pp.27 (abstract).

49. Le Pichon, X., 1968. Sea floor spreading and continental drift. Jour. Geophysical Research. Vol.13, pp.3661-3697.

50. Li Xing Xu, Wu Yi-Ming and Fu Zai-Bin., 1984.Preliminary study on mixed Permian flora from Xingjian of Gerze Distt. Xizang and its paleogeographic significance. Intern Symp. Geol. Himalaya, Vol.2, pp.38 (abstract).

51. Liang Rixuan, and Bai Wanji, 1984.Genesis of ultramafic rocks in Yarlu-Zhangbo ophiolite belt. Intern. Symp. Geol. Himalaya. Vol. 2, pp.117-118 (abstract).

52. Lin Baoyu, 1980. Lower Permian stratigraphy and coral faunas from both flanks of Yarlu-Zhangbo River in south-central Xizang (Tibet). Sino-French Co-op Invest. in Himalayas, pp.77-80.

53. Lin Baoyu and Qui Hongrong, 1984. New developments in Paleozoic stratigraphy and paleontology of Xizang (Tibet). Intern. Symp. Geol. Himalaya, Vol. 2, pp. 4-5 (abstract).

54. Li Xinqxue, 1986. The mixed Permian Cathaysia-Gondwana flora. The Paleobotanist, Vol.35, pp.211-222.

55. McKenzie, D.P. 1964. Speculations of the consequences and causes of plate motion. Jour. Geophysical Royal Astro. Society, Vol. 18, pp.1-32.

56. McElhinny, M. W., 1970. Paleomagnetism of the Cambrian Purple Sandstone from the Salt Range, Pakistan, Earth and Planetary Sci. Letter, Vol. 8, pp.149-156.

57. Mathur, Y.K. and Jain, A.K., 1980. Palynology and age of the Dras volcanic near Shergol, Ladakh, Jammu and Kashmir, India. Geosciences Journal, Vol.1, pp.55-74.

58. Meservey, R., 1979. Topological inconsistency of continental drift in the present-sized Earth. Science, Vol.166, pp. 609-611.

59. Metcalfe, I., 1996. Gondwanaland dispersion, Asian accretion and evolution of Eastern Tethys. Australian Jour. Earth Sciences, Vol.43, pp. 605-623.

60. Metcalfe, I., 1998. Paleozoic and Mesozoic geological evolution of the SE Asian region: multidisciplinary constraints and implications for biogeography. In: Hall, R. and Holloway, J. D. (Eds). Biogeography and Geological Evolution of SE Asia. Backhuys Publ. Amsterdam, pp.25-41.

61. Metcalfe, I., 2001. Warm Tethys and Cols Gondwana: East and SE Asia in Greater Gondwana during the Phanerozoic. Contributions to Geology and Paleontology of Gondwana. Cologne, pp.333-347.

62. Morgan, W.J., 1972. Deep mantle convention plumes and plate motion. Amer. Assoc. Petrol. Geologists, Bull., Vol.56, pp.203-213.

63. Nicolas, A., and 7 others.1981. The Xigaze ophiolite: a peculiar oceanic lithosphere. Nature, Vol.294, pp.414-417.

64. Norin, E., 1946. Geological exploration in western Tibet. Report of Sino-Swedish expedition. Stockholm. Aktiebolaget Thule, Vol. 29, 240.

65. Owen, H.G., 1976. Continental displacement and expansion of the Earth during Mesozoic and Cenozoic. Phil. Trans. Royal Society, London. Ser A. Vol.218, pp.223-291.

66. Pandey, O.P., and Negi, J.G., 1987. A new theory of the origin and evolution of the Deccan traps (India). Tectonophysics, Vol.142, pp.329-335.

67. Patriat, P., and Achache, J., 1984. India-Eurasia collision chronology has implications for crustal shortening and driving mechanism of plates. Nature, Vol.311, pp. 615-621.

68. Pierce, J.W., 1978. The northward motion of India since the late Cretaceous. Jour. Geophy. Royal Astro, Society, Vol.52, pp.277-311.

69. Qui Hongrong, 1980. Paleozoic and Triassic conodonts fauna in Xizang (Tibet). Sino-French Coop Invest, In Himalayas, PP.101-107.

70. Qureshy, M.N., and Warsi, W.E.K., 1981. A Bouguer anomaly map of India and its relation to broad tectonic elements of the sub-continent. Jour. Geophy. Royal Astron. Society. Vol.61, pp.235-242.

71. Raiverman, V., 1992. Trans-Asiatic lineaments and Himalayan Orogeny: In Himalayan Orogen and Global Tectonics. Sinha, A.K. (Ed). Oxford $\&$ IBH Publ. Pvt. New Delhi, pp.121-156. 
72. Raiverman, J., 2002. Foreland sedimentation in Himalayan tectonic regime: a relook at the orogenic process. B S M P S Publication, New Delhi. 378.

73. Raiverman, J., and Misra, V.N., 1975. Suru tectonic axis, Kargil area, Ladakh. Bull. Geol. Min. Met. Soc. India. Vol.48, pp.1-16.

74. Robinson, P.T., and 8 others. 2004. Ultra high pressure minerals in the Luobusa ophiolite, Tibet and their tectonic implications. Geol. Soc. London, Sp. Pub.Vol. 226, pp.247-271.

75. Romer, A.S., 1973.International correlation of Triassic Gondwana vertebrate faunas. 3rd. Intern Gondwana Symp., Canberra, pp. 469-472.

76. Saxsena, M.N., 1986. Geodynamic synopsis of the Deccan Traps in relation to epochs of volcanic activity of the Indian shield, drift of the sub-continent, and the tectonic development of southern and southeastern Asia. Jour. Southeast Asian Science, Vol.1, pp.205-213.

77. Segnor, A.M.C., 1987. Tectonic subdivisions and evolution of Asia. Tech. University, Istanbul, Bull., Vol.40, pp.355-435.

78. Sinha, A.K., 1992. Himalayan mountain building and the tectonic processes involved in it: In Himalayan Orogen and Global Tectonics. Sinha, A.K. (Ed). Oxford \& IBH Publ. Co. New Delhi, pp.3-18.

79. Sinha, A.K., 2002. Tectonics and subduction mechanism across the India-Asia collision zone in Ladakh and Karakoram. (Presidential address). 89 ${ }^{\text {th }}$ Indian Science Congress, Lucknow, pp.1-16.

80. Stauffer, P.H., 1983. Unraveling the mosaic of Paleozoic crustal blocks in SE Asia. Geol. Rundschau. Vol.73, pp.106-108.

81. Steward, J., 1982.Initial deposits in the Cordilleran Geosynclines: Evidence of a late Precambrian continental separation. Bull. Geol. Soc. Amer. Vol.83, pp.1345-1360.

82. Stocklin, J., 1981. Himalayan orogeny and earth expansion. In The Expanding Earth-A Symposium, Carey, S.W. (Ed).pp.119-130.

83. Stoneley, R., 1974. Evolution of continental margins bounding a former southern Tethys. In: The Geology of continental margins. Burk, C.A. and Drake, C.L. (Eds).Springer, New York, pp.889-903.

83. Sun Ai Lin, 1972.Permo-Triassic reptiles of Sinkiang. Scientia Sinica, 16, 151-156.

84. Tapponnier, P., Mercier, J.C. and Proust, F., 1981. The Tibetan evidence of the India-Eurasia Collision. Nature, Vol.244,pp. 410-416.

85. Tapponnier, P., Peltzer, G. and Armijo, R. 1986. On the mechanics of the collision between India and Asia. Geol. Soc. London, Sp. Publication, Vol.19, pp.115-157.

86. Upadhyay, R., and 6 others. 1999. Discovery of Gondwana plant fossils and palynomorphs of late Asselian (Early Permian) age in Karakoram block. Terra Nova, Vol.11, pp.278-283.

87. Valdiya, K.S., 1976. Himalayan transverse faults and their parallelism with subsurface structures of North India plain, Tectonophysics, Vol.32, pp.353-386.

88. Valdiya, K.S., 1988. Tectonics and evolution of the central sector of the Himalaya. Phil. Trans. Royal Society London, A326, pp.151-175.

89. Valdiya, K. S., 2015. The Making of India: Geodynamics Evolution. Springer Inter. Publ.,924.

90. Wang Naiwen, 1980. Qingzian-india paleo-continent and its welding to Cathaysia. Rept. Sino-French Coop Invest. Of Himalayas, pp.59-62.

91. Wang Naiwen, 1984. On the paleogeography and plate tectonics of Qinghai Tibet plateau. Instt. Geol. Chinese Acad. Geol. Sci. Bull., Vol.9, pp.9-28.

92. Wang Xibin, Cao Yongong, and Zheng Haixiang, 1980.Ophiolite assemblage and sequence of the middle Yarlung-Zhangbo River in Xizang (Tibet) and a model of ocean crustal evolution. Rept. Sino-French Coop Invest. Of Himalaya, pp.208-213.

93. Waterhouse, J.B., 1992. The world setting of the Himalaya during the Late Paleozoic and Mesozoic: In Himalayan Orogen and Global tectonics, (Ed) Sinha, A.K., Oxford 65 IBH Publ. Co. New Delhi, pp.289-306.

94. Waterhouse, J.B. and Bonham-Carter, G., 1975. Global distribution and character of Permian biomes based on brachiopod assemblages. Can. Jour. Earth Science, Vol.12, pp.1085-1146.

95. Waterhouse, J.B., and Jin, K., 1987. Permian stratigraphy, floras and faunas from Xizang (Tibet) their correlation, paleogeographic setting and implications from continental displacement. Contrib. Himalayan Geology, 4. 
96. Wen-Len Huan, Wang Su-Yuen, Shi Zhenjiang and Yan Jia-Quan. 1981. Distribution of earthquakes foci and plate tectonics in Qinghai-Xizang plateau and its vicinity: In Proc. Symp. Qinghai-Xizang (Tibet) Plateau, Geological and Ecological Studies of Qinghai-Xizang plateau (Eds) Liu Dong Shang et al., Science press, Beijing, Vol.1, pp.651-659.

97. Wesson, P.S. 1974.Problems of plate tectonics and continental drift. In: Plate tectonics- Assessments and Reassessments, Kahle, C.F. (Ed) Amer. Assoc. Petrol. Geologists, Mem., Vol. 23, pp.146-154.

98. Xiaochi, J., 2002. Permo-carboniferous sequences of Gondwana affinity in southwest China and their paleogeographic implications. Jour. Asian Earth Sci., Vol.20, pp.633-646.

99. Xiao Xuchang, 1980. The Xigaze ophiolite of northern Xizang (Tibet) and its relevant tectonic problems. Rept. Sino-French Invest. Co-op. Of Himalaya, pp.164-168.

100. Xiong Shaobai, Teng Jiwan and Yen Zhouxun, 1984. The thickness of the crust and variability of the Moho discontinuity at the south Xizang (Tibet). Inter. Symp. Geol. Himalaya. Vol. 1, pp.154-156 (abstract).

101. Xu Baowen, Badengzhu and Zheng Haoyang, 1984. Is the suture between the Indian plate and Eurasian plate in Xizang? Inter. Symp. Geol. Himalaya 1, $48-50$ (abstract).

102. Zhang Changzhou and Wui Shizhi, 1984. On the division of stages of Himalayan tectonic movement and the shaping of Qinghai and Xizang (Tibet). Inter. Symp. Geol. Himalaya, Vol.1, pp.83-84 (abstract).

103. Zheng Haixiang, 1984. Is the Yarlung-Zhangbo (Tsangpo) tectonic belt a suture? Inter. Symp Geol. Himalaya, Vol.2, pp.71 (abstract).

104. Zhao, W. and Morgan, W. J., 1987. Injection of Indian crust into Tibetan lower crust: a two-dimensional finite element model study. Tectonics, Vol.6, pp.489-504. 